\title{
SISTEM KEKERABATAN MATRILINEAL DALAM ADAT MINANGKABAU PADA NOVEL SITI NURBAYA: KASIH TAK SAMPAI KARYA MARAH RUSLI
}

\author{
Arif Setiawan \\ Pendidikan Bahasa dan Sastra Indonesia \\ Universitas Muhammadiyah Malang \\ arifsetiawan@umm.ac.id
}

\begin{abstract}
Abstrak:Penelitian ini bertujuan untuk mendeskripsikan sistem kekerabatan Minangkabau dalam novel Siti Nurbaya: Kasih Tak Sampai karya Marah Rusli.Hal ini didasari oleh keberadaan garis keturunan yang dianut oleh masyarakat Minangkabau yang bersifat matrilineal, sehingga menempatkan perempuan menjadi salah satu pengambil keputusan di lingkup keluarga. Penelitian ini menggunakan metode penelitian deskriptif kualitatif. Data dalam penelitian ini berupa sekuen cerita dalam novel Siti Nurbaya: Kasih Tak Sampai karya Marah Rusli. Sumber data dalam penelitian ini adalah novel Siti Nurbaya: Kasih Tak Sampai Karya Marah Rusli yang diterbitkan pada tahun 1922 oleh angkatan Balai Pustaka dengan tebal 291 halaman. Setelah semua data terkumpul, maka dianalisis menggunakan analisis data model Milles dan Hubberman yang terdiri dari (1) reduksi data, (2) penyajian data, dan (3) penarikan kesimpulan. Hasil penelitian menunjukkan bahwa dalam novel Siti Nurbaya: Kasih Tak Sampai menampilkan sistem kekerabatan matrilineal yang sangat kental meliputi (1) perempuan memegang penuh peranan dalam keluarga dan (2) perempuan menjadi pengambil keputusan dalam keluarga.
\end{abstract}

\section{Kata kunci: Kekerabatan, Perempuan, Matrilineal}

Abstract:This study aims to describe the Minangkabau kinship system in Siti Nurbaya's novel: Love Not Until the work of Marah Rusli. This is based on the existence of the lineage adopted by the Minangkabau community which is matrilineal in nature, thus placing women as one of the decision makers in the family sphere. This study uses a qualitative descriptive research method. The data in this study is a sequence of stories in Siti Nurbaya's novel: Love Not Until the work of Marah Rusli. The source of the data in this study is Siti Nurbaya's novel: Love Is Not Up to Angry Rusli's Works published in 1922 by the 291-page Balai Pustaka force. After all the data has been collected, it is analyzed using Milles and Hubberman data analysis which consists of (1) data reduction, (2) data presentation, and (3) conclusion drawing. The results showed that in Siti Nurbaya's novel: Love 
Not Until displaying a very thick matrilineal kinship system includes (1) women holding full roles in the family and (2) women becoming decision makers in the family.

\section{Keywords: Kinship, Women, Matrilineal}

\section{PENDAHULUAN}

Minangkabau merupakan salah satu suku yang terbesar di nusantara serta mendiami wilayah yang terletak di Sumatera Barat. Suku Minangkabau sangat terkenal sebagai suku yang gemar merantau, sehingga banyak menyebar di seluruh penjuru nusantara. Selain itu, suku Minangkabau juga terkenal dengan kebudayaan yang melekat di dalamnya. Kebudayaan yang terdapat di suku Minangkabau tergolong sangat unik dan khas. Kekhasan tersebut dapat dicermati melalui garis keturunan yang dianutnya yaitu matrilineal. Berbanding terbalik dengan suku lainnya di nusantara yang lebih banyak menganut garis keturunan berdasarkan garis keturnanan ayah atau patrilineal. Hal ini seolah meneguhkan bahwa nenek moyang masyarakat Minangkabau telah menetapkan hati untuk menentukan garis keturunan berdasarkan garis keturunan ibu.
Sistem kepercayaaan kekerabatan ini seolah telah mengakar dan menjadi nilai dalam kehidupan masyarakat Minangkabau yang sulit dibantah.

Sistem kekerabatan yang begitu kental dan mengakar tersebut tidak hanya berlaku begitu saja dan berjalan dengan sendirinya. Hal ini dikarenakan dalam kehidupan seharihari masyarakat Minangkabau telah melaksanakan dan menjalankan sistem kekerabatan berdasarkan asas-asas yang telah berlaku (Meiyanti, 2014:58). Asas dan sistem kekerabatan matrilineal masyarakat Minangkabau memilikitiga ciri khas yang meliputi (1) garis keturunan dihitung berdasarkan garis keturunan ibu, (2) suku anak yang dihitung berdasarkan suku dari ibu, dalam pepatah Minangkabau disebutkan bahwa Basuku kabakeh ibu, Babangso Kabakeh ayah, jauah mancari suku dakek mancari ibu, Tabang basitumpu Hinggok mancakam, dan(3) Pusako 
tinggi turun dari mamak $k a$ kamanakan, pusako randah turun dari bapak kapado anak (Misnal, 2015:3).

Dengan ciri yang telah melekat tersebut seolah meneguhkan bahwa peran perempuan sangat penting dalam kebudayaan Minangkabau. Posisi perempuan di tengah masyarakat memiliki kedudukan yang sangat ditinggikan. Hal ini menjadi salah satu ciri khas yang membedakan Minangkabau dengan daerah lain yang berada di Indonesia. Selian itu, perempuan di masyarakat Minangkabau digambarkan sebagai penghias nagari (kampung) (Bahri, 2014:35). Pemosisian tersebut bukan hanya berlaku sebagai simbol semata, melainkan secara benar-benar diberikan peran sesuai dengan posisi tersebut di tengah masyarakat. Oleh karena itu, perempuan Minangkabau dalam adat memiliki tempat dalam pengambilan keputusan dalam setiap musyawarah yang diadakan di dalam nagari, walaupun pada dasarnya mereka bukan berperan dalam mengambil keputusan (Fatimah, 2017:15).
Pada tahun 2015 terdapat artikel ilmiah yang ditulis oleh Misnal dengan judul Sistem Kekerabatan dalam Kebudayaan Minangkabau: Perspektif Aliran Filsafat Strukturalisme Jean Claude LeviStrauss. Misnal mencoba memaparkan bagaimana sistem kekerabatan dengan hasil sistem kekerabatan matrilineal Minangkabau menempatkan perempuan sebagai pewaris harta kekayaan dan laki-laki sebagai pihak yang berpindah ke rumah perempuan. Artikel ilmiah kedua yang juga memiliki keterkaitan dengan apa yang sudah dituliskan oleh Misnal, yaitu ulasan dari Iva (2015) yang mengangkat judul tentang Nilai Filosofis Budaya Matrilineal di Minangkabau (Relevansinya bagi Pengembangan Hak-Hak Perempuan di Indonesia). Iva memaparkan mengenai esensi budaya matrilineal adat Minangkabau menurut filsafat feminisme.

Seolah melanjutkan kedua penelitian yang telah dilakukan sebelumnya, penelitian ini lebih menekankan pada sistem kekerabatan Minangkabau yang terdapat dalam 
novel Siti Nurbaya: Kasih Tak Sampai karya Marah Rusli. Berdasarkan ulasan dan penelitian terdahulu yang telah dipaparkan sebelumnya, maka dalam penelitian ini akan menguraikan mengenai sistem kekerabatan Minangkabau dari sisi peran perempuan dalam keluarga.

\section{METODE}

Sesuai dengan tujuan dan permasalahan yang dipaparkan, maka metode yang digunakan dalam penelitian adalah metode deskriptif kualitatif. Metode ini digunakan untuk mendeskripsikan dan mengintepretasi data-data yang tertulis dalam novel Siti Nurbaya: Kasih Tak Sampai karya Marah Rusli. Sumber data dalam penelitian ini adalah novel Siti Nurbaya: Kasih Tak Sampai karya Marah Rusli yang diterbitkan oleh Balai Pustaka pada tahun 1922 dengan jumlah 291 halaman. Data dalam penelitian ini mencakup satuan cerita yang terwujud dalam dialog, monolog, paragraf,sekuen cerita, bagian kalimat, maupun narasi tokoh yang menunjukan sistem kekerabatan dalam adat Minangkabau. Teknik pengumpulan data yang dilakukan adalah menggunakan teknik studi dokumentasi.Teknik ini dilakukan berdasarkan tujuan penelitian, yakni memberikan gambaran sistem kekerabatan dalam adat Minangkabau. Pengumpulan data dilakukan dengan teknik studi dokumentasi atau studi kepustakaan dengan disertai pemahaman arti secara mendalam (sinverstehen) dan pemerian mendalam (thickdescription) (Moleong, 2010:67). Langkah-langkah yang dilakukan dalam proses analisis data adalah sesuai dengan rancangan analisis data yang dipaparkan oleh Miles dan Huberman (Creswell, 2014:56). Model analisis data yang digunakan adalah flow model of analysis yang prosesnya dilakukan dengan langkah-langkah penyeleksian data, (2) pemaparan data, dan (3) penarikan kesimpulan.

\section{HASIL DAN PEMBAHASAN}

Dalam sistem matrilineal, perempuan memiliki hak yang penuh terhadap rumah gadang yang ditempatinya, sedangkan laki-laki hanya menumpang saja. Dalam sistem 
ini seorang anak perempuan yang telah menikah tinggal pada bilik-bilik (kamar) bersama suami mereka, sedangkananak perempuan yang belum dewasa masih tidur bersama saura perempuan lain di ruang tengah (Nurwani, 2012:67). Hal ini semakin memperkuat betapa kuatnya pengaruh dari perempuan dalam adat Minangkabau, sebagaimana data berikut ini.

\footnotetext{
"Suatu lagi yang tak baik," kata Ahmad Maulana; sedang senyumnya hilang dari dirinya, "perkawinan itu dipandang sebagai perniagaan. Di negeri lain, perempuan yang dijual kepada laki-laki, artinya si laki-laki harus memberi uang kepada si perempuan; akan tetapi di sini, laki-laki dibeli oleh perempuan, sebab perempuan; memberi uang kepada lakilaki." (Rusli, 1922:361)
}

Ahmad Maulana merasa dirinya tidak memiliki harga diri dalam memposisikan dirinya dalam pandangan adat Minangkabau. Dirinya menyampikan bahwa seorang laki-laki tidak memiliki kekuasaan apa-apa dikarenakan dalam adat Minangkabau laki-laki yang dibeli oleh perempuan. Hal ini menjadikan Ahmad Maulana merasa tidak memiliki hakatas apapun dalam keluarga. Tidak hanya itu saja, Ahmad Maulana juga menganggap bahwa perkawainan tidak lebih sekedar sebuah proses perniagaan semata. Di mana sebuah perkawinan hanya dipandang sebatas pemberian uang sebagai penggantinya. Dengan sistem yang demikian, maka siapa yang mampu membeli salah satu pihak akan memiliki kekuasaan yang bersifat penuh. Hal ini yang membuat Ahmad Maulana membandingkan adat yang ada di Minangkabau dengan tempat lain yang memandang laki-lakitidak memiliki peran penuh dalam sebuah keluarga.

Kondisi yang demikian semakin memberikan penguatan bahwa perempuan memiliki peran yang begitu dominan dalam keluarga. Kondisi demikan senada dengan apa yang telah diuangkapkan oleh Nurwani (2012:67)bahwa perempuan memiliki hak yang penuh terhadap rumah gadang yang ditempatinya. Berdasarkan paparan tersebut maka dapat dipastikan bahwa perempuan memiliki kekuasaan penuh terhadap keluarga, sehingga membuat laki-laki 
hanya sebatas pelengkap saja.Hal ini seolah menguatkan adat Minangkabau bahwa perempuan memegang peran penuh dalam lingkup keluarga. Ungkapan kegalauan tersebut masih terasa menyesakkan bagi Ahmad Maulana, sehingga membuatnya terus mengomel. Hal ini terlihat dalam kutipan data berikut ini.

"Bukan aku lupa," jawab Ahmad Maulana. "Itulah yang lebih terasa di hatiku. Lakilaki tak usah memberi belanja dan memelihara anak istrinya, bahkan dapat makan dan pakaian pula dari perempuan. Dan apabila laki-laki itu berbangsa, tatkala kawin, dijemput pula oleh perempuan, dengan uang dan pakaian. Jadi apa namanya laki-laki itu? Karena sesungguhnya laki-laki itulah yang harus memberi nafkah dan memelihara anak istrinya, sebab perempuan lebih lemah dari laki-laki." (Rusli, 1922:367).

Seolah belum puas dengan apa yang dikeluhkannya mengenai posisi laki-laki yang tidak mampu berbicara banyak dalam mengambil keputusan di lingkup keluarga. Dalam adat Minangkabau seorang laki-laki tidak memiliki peran yang sangat krusial. Bahkan dalam
perkawinan pun demikian,
perempuan mendapatkan peran
yang begitu luar biasa. Dalam
perkawinan pun perempuan yang
memberikan uang dan pakaian
kepada pihak laki-laki, apabila
pihak laki-laki berasal dari kaum
bangsawan, maka pihak laki-laki
dijemput oleh pihak perempuan.
Hal ini yang menjadikan Ahmad
Maulana merasa tidak memiliki
peran apapun dalam lingkup
keluarga, bahkan dimulai
semenjak mereka menikah. Kalau seperti itu kondisi yang dialami oleh laki-laki, maka apa sebutan yang harus dialamatkan pada laki-laki. Selain itu, Ahmad Maulana juga membandingkan apa yang harus dilakukan oleh seorang laki-laki,karena laki-laki harus bertangggung jawab memberi nafkah terhadap perempuan dan bukan sebaliknya.

Hal senada $\begin{array}{r}\text { juga } \\ \text { diungkapkan oleh }\end{array}$ Navis,
1984:56) bahwa perempuan
memiliki dan memegang peran


penuh dalam lingkup keluarga.

Kondisi demikian merupakan aturan adat yang telah secara turun temurun menjadi adat yang menglair dalam kehidupan masyarakat Minangkabau. Perempuan memegang peran penuh dalam lingkup keluarga melebihi seorang laki-laki, sehingga dalam segala hal yang berkaitan dengan keuputusan keluarga selalu berada di tangannya. Hal ini membuktikan bahwa perempuan menjadi sosok yang memegang penuh peranan dalam lingkup keluarga, sehingga membuat laki-laki tidak memiliki peran aapapun selain hanya sebagi pelengkap saja.

"Memang engkaulah
saudaraku yang sesungguh-
sungguhnya, membangkitkan
batang terendam, yang tahu
adat istiadat dan menjunjung
tinggi kebangsawanan kita
dan menjalankan kewajiban
kepada saudara dan
kemenakannya," kata putri
Rubiah, memuji-muji adiknya
itu." (Hal. 90)

Dalam sebuah ruangan kecil di rumah adat, Putri Rubiah tengah bercakap dengan saudara perempuannya. Percakapan

panjang yang telah dilakukan oleh keduanya seolah telah banyak membahas hal yang terjadi dalam keseharian mereka. Di satu sisi Putri Rubiah menyampaikan ucapan terima kasih kepada saudaranya yang telah banyak mengingatkan pada adat istiadat. Sebagai seorang perempuan dari kalangan bangsawan tentunya Putri Rubiah memiliki banyak tanggung jawab terhadap saudara dan kemenakannya. Sedikit lali saja tentunya akan sangat membuat kerugian yang cukup besar terhadap saudara dan kemenakannya. Kelalaian tersebut coba diingatkan oleh adik dari Putri Rubiah agar tidak terjadi berlarut-larut, sehingga memantik kesadaran dalam dirinya. Putri Rubiah memujimuji adiknya yang telah mengingatkannya atas tanggung jawabnya dalam keluarga.

Apa yang telah dilakukan oleh adik putri Rubiah merupakan sebuah pesan 
tersendiri yang patut dipikirkan dengan baik oleh Putri Rubiah. Hal ini dikarenakan perempuan dalam adat Minangkabau memang memiliki peranan penuh dalam keluarga. Senada dengan yang disampaikan oleh Monica (2012:227) yang memaparkan bahwa perempuan memegang peran penuh dalam keluarga, sehingga apapun yang dilakukan oleh perempuan itu akan menjadi sebuah tanda kekuasaan di dalam keluarga. Kondisi demikian yang tengah dialami oleh Putri Rubiah, melalui adiknya ada sebuah pesan yang disampaikan kepadanya untuk tetap berlaku sebagaimana perempuan

Minangkabau pada semestinya.

"Ayahnya?" tanya Ahmad Maulana, sambil memandang istrinya dengan merengut. "Uh, masakan mau ia menanggung beban itu! Bukankah telah menjadi adat di sini, anak pulang kepada mamak. Orang bangsawan sebagai Sutan Hamzah pula, 'kan suka menyelenggarakan anaknya; sedangkan dirinya sendiri tak terurus olehnya!" (Hal 357)
Ahmad Maulana bertanya kepada istrinya dengan raut wajah yang tidak biasanya, seloroh yang kemudian keluar adalah kembali lagi mempermasalahkan peran penuh perempuan dalam adat Minangkabau. Seloroh tersebut ditekankan dengan nada yang cukup tinggi, bahwa dalam adat Minangkabau anak akan pulang kepada mamaknya yang telah membesarkannya. Bahkan dalam keluarga laki-laki yang tergolong bangsawan pun, perempuan juga memegang peranan penuh dalam lingkup keluarga. Bahkan apa yang tengah dialami oleh lelaki bangsawan seperti Sutan Hamzah pun yang memiliki banyak anak, juga sangat memprihatinkan. Jumlah anak yang banyak tersebut sampai harus membuat diri Sutan Hamzah seolah tidak terurus dengan baik. Seolah apa yang terjadi pada Sutan Hamzah merupakan cerminan betapa perempuan Minangkabau memegang penuh peran dalam keluarga. 


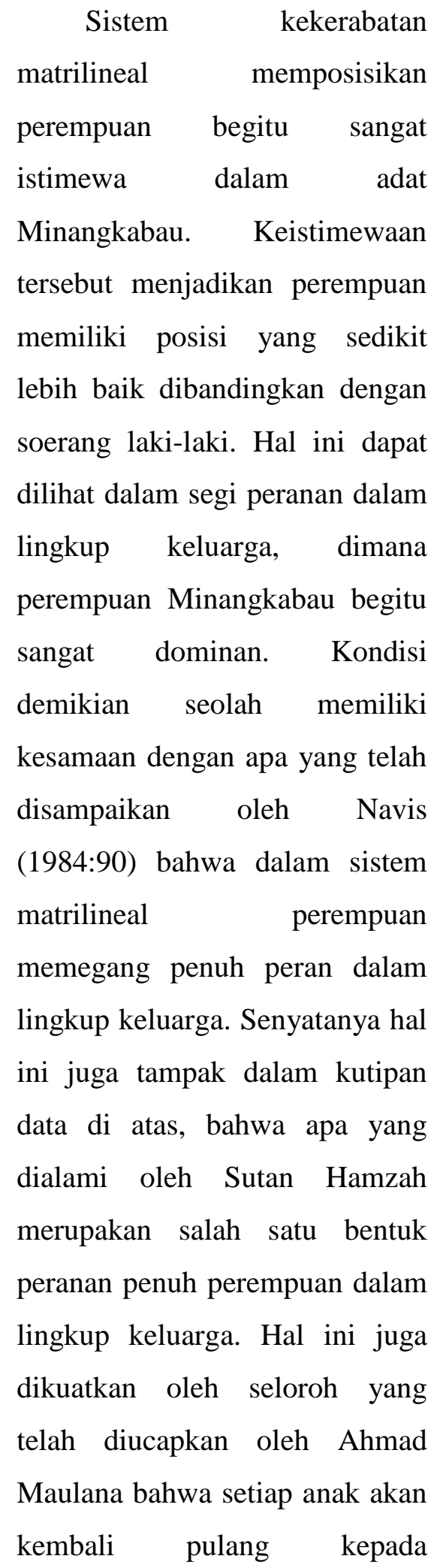

mamaknya sesuai dengan adat dan kebiasaan di Minangkabau.

"Ada orang yang bersangka, anak itu sesungguhnya terlebih dekat dengan mamaknya daripada bapaknya, karena itu terang kemanakan mamaknya, sebab kelihatan dilahirkan oleh saudara si mamak itu, yang sedarah dengan dia. Tetapi ia belum tentu anak si bapa; boleh, jadi juga anak laki-laki lain, yaitu kalau ibunya tiada setia kepada suaminya." (Hal.371-372)

Kembali apa yang disampikan oleh Ahmad Maulana mengenai kondisi yang begitu jelas terpapar di masyarakat Minangkabau. Suara yang muncul seolah merupakan bisikan dari suara hati yang seolah diungkapkan berdasarkan realita. Masyarakat begitu menerima dengan begitu saja apa yang sudah ada dan enggan untuk menelisik lebih dalam. Hal ini dicontohkan oleh Ahmad Maulana bahwa sebagian besar anak yang telah lahir di Minangkabau, maka akan selalu memiliki hubungan yang lebih dekat dengan mamaknya atau 
ibunya daripada dengan ayahnya.

Kondisi tersebut seolah menguatkan hubungan darah yang begitu kental terhubung dengan mamak atau ibu, tidak dengan ayah, sehingga masyarakat Minangkabau menjadikan perempuan lebih istimewa daripada laki-laki. Namun, apa yang selama ini telah mengakar erat di masyarakat Minangkabau seolah diusik oleh Ahmad Maulana dengan pernyataan yang sedikit aneh. Dia menyampaikan bahwa anak yang telah dilahirkan tersebut belum tentu anak dari mamak atau ibu, tetapi tidak menutup kemungkinan bahwa anak tersebut adalah anak dari laki-laki lain. Apa yang telah disampaikan oleh Ahmad Maulan seolah menunjukkan bahwa dengan sistem kekerabatan yang melekat erat di masyarakat Minangkabau, akan membuat perempuan semakin leluasa untuk melakukan hal yang tidak sebagaimana mestinya. Salah satu hal yang tidak semestinya tersebut menurut Ahmad Maulana adalah perselingkuhan yang dilakukan oleh perempuan. Asumsi tersebut seolah menjadi pikiran Ahmad Maulana dalam mencermati kedudukan dan sistem kekerabatan yang dianut oleh masyarakat Minangkabau.

Sistem kekerabatan yang dianut oleh masyarakat Minangkabau telah memberikan posisi yang teramat istimewa kepada perempuan dalam adat Minangkabau. Apa yang telah didapatkan oleh perempuan seolah memberikan gambaran bahwa posisi perempuan lebih baik dari laki-laki. Kondisi tersebut tergambar nyata dalam pengambilan peran dalam rumah tangga yang lebih didominasi oleh perempuan daripada lakilaki. Selain itu, apa saja yang ada di sekitar perempuan seolah juga mendapatkan hak yang sangat istimewa. Salah satunya yang menjadi sorotoan di dalam kutipan data di atas adalah anak yang telah dilahirkan akan 
memiliki hubungan yang begitu erat dengan mamak atau ibu daripada ayah. Kondisi demikian seolah memiliki kesamaan dengan apa yang telah disampaikan oleh Navis (1984:90) bahwa dalam sistem matrilineal perempuan memegang penuh peran dalam lingkup keluarga. Nyatanya memang apa yang telah diungkapkan oleh Ahmad Maulana seolah tidak menutup kemungkinan bahwa dengan semua yang dimiliki, ada hal yang dapat dilakukan oleh perempuan. Hal yang dapat dilakukan oleh perempuan digambarkan oleh Ahmad Maulana seolah sama persis dengan seorang laki-laki yang memiliki kelebihan segalanya.

"Di sisi gudang bercakapcakap seorang perempuan tua dengan anaknya yang rupanya hendak berlayar, sambil memberi nasihat, supaya anaknya berhati-hati di jalan dan di negeri orang. Di atas batu duduk seorang laki-laki tua bertutur-tutur dengan saudaranya, yang rupanya pun hendak meninggalkan tanah airnya, berlayar mencari penghidupan di rantau orang." (Hal. 131)

Kebiasaan masyarakat Minangkabau yang telah turun temurun, sampai hari ini tetap terjaga dan terpelihara. Masyarakat Minangkabau sedari kecil telah dibiasakan untuk mengajarkan kepada anakanya. Perempuan semanjak kecil diperbolehkan hidup dan dekat dengan mamak, sedangkan anak laki-laki, semenjak kecil diajarkan untuk tidur di surau-surau. Kondisi demikian seolah telah membentuk pola berpikir dan pedoman hidup bagi masyarakat Minangkabau. Hal ini terlihat dari kutipan data di atas yang menggambarkan seorang anak lakilaki hendak berlayar dan merantau ke negeri orang. Apa yang telah dilakukan oleh anak tersebut seolah menjadi titik akumulasi keseharian yang dia dapati selama di Minangkabau. Pola pikir dan jiwanya telah dibentuk untuk berjauhan dari mamak atau ibu, sehingga setiap mereka beranjak besar akan selalu merantau dan keluar dari Minangkabau. Pola tersebut seolah telah menjadi kebiasaan dan mengakar 
begitu kuat bagi laki-laki yang berada di Minangkabau. Merantau dijadikan sebagai sebuah pilihan untuk membuktikan bahwa seorang laki-laki juga dapat menjadi seorang yang memiliki peran dalam memegang dan megambil keputusan dalam keluarga.

Sistem kekerabatan yang dianut oleh Masyarakat Minangkabau telah memberikan dampak yang nyata dalam kehidupan. Dampak tersebut telah membuat sebagian besar laki-laki seolah ingin membuktikan bahwa mereka juga memiliki kesempatan yang sama untuk mengambil keputusan. Kondisi yang demikian, membuat sebagian besar laki-laki ketika beranjak dewasa akan merantau ke luar Minangkabau. Hal ini dianggap sebagai salah satu jalan dan jawaban bagi laki-laki untuk keluar dari sistem dan mendapatkan hak yang sama dengan perempuan. Kondisi yang demikian, sedikit berlawanan dengan sistem kekarabatan yang dianut oleh masyarakat Minangkabau yang menempatkan perempuan lebih dari laki-laki. Selian itu, pendapat yang disampaikan oleh Navis (1984:99) bahwa sistem metrilineal seorang perempuan memegang penuh peran di dalam lingkup keluarga, seolah menjadi pembakar semangat sebagian besar laki-laki Minangkabau untuk merantau. Pilihan tersebut diambil sebagai jawaban untuk membuktikan bahwa laki-laki juga berhak mendapatkan hal yang sama seperti halnya perempuan, sehingga tidak lagi menjadi bagian yang terpinggirkan dalam lingkup keluarga. Selain itu, merantau juga dianggap sebagai sebuah sistem yang dapat mengubah peruntungan kehidupan bagi laki-laki Minangkabau. Setelah sekian lama merantau dan dianggap sukses maka laki-laki akan pulang dan menjadi buah bibir bagi masyarakat di sekitarnya.

\section{SIMPULAN}

Sistem kekrabatan yang dianut oleh masyarakat Minangkabau menekankan pada sistem matrilineal yang bertumpu pada garis keturunan mamak atau ibu. Sistem kekerabatan tersebut menjadikan peran perempuan sangat dominan dan berpengruh. Kondisi yang demikian membuat peran laki-laki tidak begitu terlihat 
bahkan dapat dikatakan tidak ada. Ketiadaan peran laki-laki tersebut memberikan perempuan ruang yang begitu luas dalam lingkup keluarga. Hal ini terlihat jelas dalam novel Siti Nurbaya: Kasih Tak Sampai karya Marah Rusli bahwa perempuan Minangkabau memegang penuh peranan dalam keluarga dan perempuan menjadi pengambil keputusan dalam keluarga. Hasil penelitian ini seolah menguatkan keberadaan sistem kekerabatan matrilineal yang memberikan segala keputusan kepada pihak perempauan baik dalam lingkup keluarga maupun di lingkup publik. Selain itu, perempuan juga memiliki hak waris yang lebih daripada laki-laki, sehingga warisan yang didapatkan akan berbeda antara perempuan dan laki-laki.

\section{DAFTAR PUSTAKA}

Bahri, A. (2014). Nilai-nilai Demokratis dan Eksistensi Kebudayaan Padang. Jurnal Suluah, 4(5), 34-47.

Creswell, J. W. (2014). Research Design: Qualitative, Quantitative and Mixed Methods Approaches. Thousand Oaks, CA: Sage Publications Inc.

Fatimah, S. (2017). Gender dalam Komunitas Masyarakat
Minangkabau; Teori, Praktek dan Ruang Lingkup Kajian. Jurnal Ilmiah Kajian Gender, 10(1), 1024.

Iva, A. (2015). Nilai Filosofis Budaya Matrilineal di Minangkabau (Relevansinya bagi Pengembangan Hak-Hak Perempuan di Indonesia). Jurnal Filsafat, 25(1), 32-55.

Meiyanti, S. (2014). Perubahan Istilah Kekerabatan dan Hubungannya dengan Sistem Kekerabatan Pada Masyarakat Minangkabau. Jurnal Antropoplogi: Isu-Isu Sosial Dan Budaya, 16(1), 57-64.

Misnal, M. (2015). Sistem Kekerabatan dalam Kebudayaan Minangkabau: Perspektif Aliran Filsafat Strukturalisme Jean Claude Levi-Strauss. Jurnal Filsafat, 25(1-31).

Moleong, J. L. (2010). Metodologi Penelitian Kualitatif. Bandung: Remaja Rosdakarya.

Monica, S. Z. (2012). Keberlanjutan Sistem Matrilineal Keluarga Muda Minang di Era Globalisasi. In Prosiding Seminar Internasional Multikultural dan Globalisasi (pp. 225-237).

Navis, A. A. (1984). Alam Terkembang Jadi Guru: Adat dan Kebudayaan Minangkabau. Jakarta: Grafitti Press.

Nurwani. (2012). Perempuan Minangkabau dalam Metafora Kekuasaan. Jakarta: Pustaka Pelajar.

Rusli, M. (1922). Siti Nurbaya: Kasih Tak Sampai. Jakarta: Balai Pustaka. 